臨床 最近の 2 症例からみたイタイイタイ病の発症機転と 病態 とくにビタミン D代謝について

富山医科薬科大学医学部公塚语生学

青島 恵子○ 寺西 秀豊 加須屋 実
萩野病院
萩野 昇

\title{
PATHOGENESIS AND PATHOPHYSIOLOGY OF ITAI-ITAI DISEASE: A REPORT OF TWO CASES AND ITS CLINICALSTUDY
}

Keiko Aoshima, MD, Hidetoyo Teranishi, MD, and Minoru KasuYa, MD

The Department of Public Health, Faculty of Medicine,

Toyama Medical and Pharmaceutical University

Noboru HAGINO, MD

Hagino Hospital

\begin{abstract}
概要 運動痛，歩行困難を主訴としたイタイイタイ病の 2 症例について，発症機転ならびに病 態について検討した，症例 1 は66才，女性。1978年頃上り右股関節痛，歩行困難，助骨痛など が出現するも放置，1980年 8 月萩野病院を初診．症例 2 は63才，女性. 1980年 1 月左股関節痛 のため歩行困難となり, 同年 8 月某病院整形外科で骨軟化店上診断される. 歩行がより困難上 なり，1981年 5 月萩野病院を初診。症例 1 は肋骨，大腿骨に多発性の偽骨折を認め，血清Ca 7.8, P 2.3mg/dl, Alk-P-ase 28.5KAU, 症例 2 は左大腿骨䅡部に偽骨折を認め, 血清Ca 8.9, P 2.1 $\mathrm{mg} / \mathrm{dl}$, Alk-P-ase 64.2KAUであつた。.以上の所見から骨軟化症と診断した。 また 2 症例は， 腎性糖尿，低分子蛋白尿，アミノ酸尿，\%TRPの低下, 代謝性アシドーシスを示し，多発性の尿 細管障害む認めた。 2 症例はカドミウム濃厚污染地に40年以上居住し, 尿中 血中カドミウム 値は高値を示した。このことから尿細管障害の原因は, 環境中カドミウム暴露によるものと考 古られ，骨軟化症は尿細管障害によるもの(イタイイタイ病)と診断した。2症例は1967年の 住民健診で，泉糖・尿蛋白陽性を指摘されていたことから，尿細管障害の発症は1967年以前々 考克られ，尿細管障害による低りン酸血症，代謝性アシドーシスの病態の長期持続が骨軟化症 の主要な原因々考克られた，血中1 $\alpha$ ，25-dihydroxy vitamin Dは症例 1 で低下，症例 2 は正常 であつた。症例 1 は糸球体機能の低下があり，腎障害の進展した例では腎でのビタミンD代謝 障害を認めた。
\end{abstract}

\section{緒言}

富山県神通川流域のカドミウム（以下Cdと略 す) 污染地域に多発したイタイイタイ病（以下イ 病と略す)は，Cdを原因とする公害疾患として広 く知られている．1967年に患者認定制度が設けら れて以後，1983年 6 月までに患者と認定された者

〔昭和58年 8 月 9 日受稿〕
141名，要観察と判定された者318名にのぼつてい る.

本病の臨床症状については，すでに骨所見を中 心に明らかにされている11.中川は骨所見と症状 からイ病の重症度を分類し，「いわゆるWatchel. gang（あひる様歩行）を行なう例を軽症」とし， 今日ではほとんどみることができない「骨格变形 著しく随意運動が困難で, 殆ど静止状態にある例」 
を重症としている゙。しかしイ病においてこのよ うな骨症状を示す臨床像は，その病期としては最 末期と考えられる。なぜならばイ病はその後の研 究から, 本病発生地域住民中の多数にみられる尿 細管障害例が骨病変を呈するに至つたものと考兄 られるからである2．腎障害と骨病変の関連につ いて斎藤らは，ビタミンD治療そのほかによる病 像の修飾をらける以前に，尿細管障害があつたこ とを, 中川らの症例報告について詳細に検討し明 らかにしている゙!.

現在イ病の発症機転は, Cdによつてひき括こさ れた尿細管機能異常に基づく骨軟化症（renal tubular osteomalacia）之理解されている334). し かしながら, 本病研究の初期に, 骨病変を中心と した臨床報告がなされて以降，イ病の発症経過， 臨床像，生活環境歴などについて詳細に検討した 症例報告はきわめて少なく，またイ病の病態につ いても必ずしも十分に明らかにされているわけで はない。

ここでは1967年の住民健康調査で糖尿・蛋白尿
を指摘され，13～14年後の $1980 － 81$ 年の初診時に 股関節痛ととれによる歩行困難を主訴とし，さら にX線像上明白な骨軟化症(骨改変層)を認め，1 病と診断した 2 症例について報告し，本病の発症 機転について検討する。またイ病の病態について， リン酸代謝とビタミン D代謝に限つて考察を加え て報告する。

\section{症例}

症例 1：66才，女性。

初診：1980年 8 月.

主訴：右股関節痛とそのための歩行障害，腰 痛, 右肋骨痛.

家族歴： 特記することなし。

既往歴・生活歴（Table 1)：生来著患なく健 康であつた．1933年（19才）よりCd污染地域であ る現住所地の上新川郡大沢野町東大久保に居住す る．家業は農業である，居住当初の领料・生活用・ 農業用などの水は，神通川より取水する大久保用 水の水を用いていた，数年後井戸を設置し领料用 としたが，洗濯などの生活用の水は用水の水を用

Table 1. Present, personal and social history of the case 1.

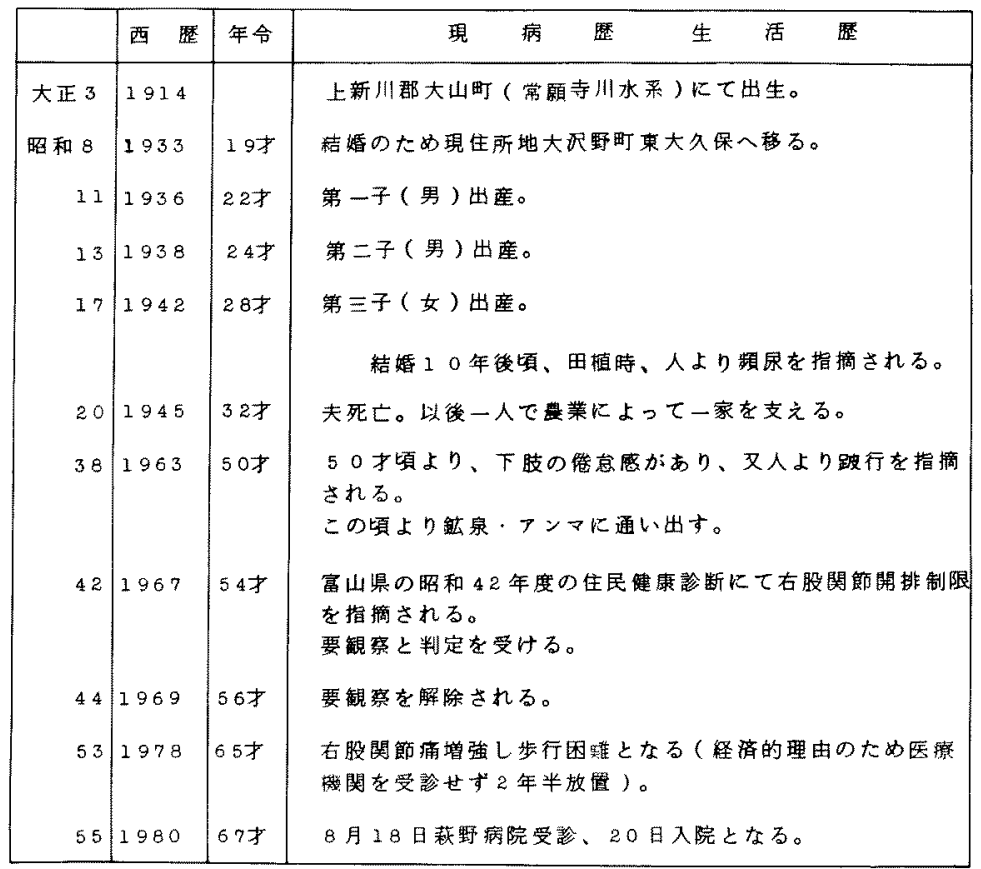


いた。また農作業時には，用水の水を直接飲用し t.

現病歴：50才（1963年）頃より下肢の倦意感 が出現し，人より跛行を指摘された。1967年富山 目が実施した住民健康診査に扎いて右股関節開排
制限を指摘された。この結果要観察者の判定をら ける。しかし 2 年後の1969年に要観察者の大部分 がその判定を解除された際に解除されていた。そ の後徐々に体動痛は体全体に払がり，1978年頃よ り主訴にある痛みが著明となり，そのため歩行な

Table 2. Laboratory data on two patients with itai-itai disease.

\begin{tabular}{|c|c|c|c|}
\hline & & Case 1 & Case 2 \\
\hline Height & $\mathrm{cm}$ & 153 & 142 \\
\hline Weight & $\mathrm{Kg}$ & 45 & 37 \\
\hline $\mathrm{BP}$ & $\mathrm{mnH} g$ & $162 / 98$ & $132 / 86$ \\
\hline \multicolumn{4}{|l|}{ Blood count } \\
\hline WBC & $4^{/ \mathrm{mm}_{3}^{3}}$ & 6200 & 3700 \\
\hline $\mathrm{RBC}$ & $10^{4} / \mathrm{mm}^{3}$ & 328 & 341 \\
\hline Hemoglobin & $\mathrm{g} / \mathrm{dl}$ & 9.2 & 12.1 \\
\hline Hematocritt & $\%$ & 30 & 36 \\
\hline \multicolumn{4}{|l|}{ Blood Chemistry } \\
\hline Total protein & $g / d 1$ & 7.0 & 7.2 \\
\hline Albumin & $\%$ & 69.4 & 68.9 \\
\hline$\alpha_{1}-$ globulin & & 2.3 & 3.5 \\
\hline$\alpha_{2}$ & & 7.6 & 10.3 \\
\hline$\beta$ & & 7.0 & 7.2 \\
\hline$\gamma$ & & 13.7 & 10.1 \\
\hline Fasting blood sugar & $\mathrm{mg} / \mathrm{dl}$ & 96 & 90 \\
\hline Urea nitrogen & & 27 & 12 \\
\hline Uric acid & & 5.9 & 4.8 \\
\hline Creatinine & & 2.7 & 1.2 \\
\hline Cholesterol & & 146 & 106 \\
\hline GOT & U & 12 & 9 \\
\hline GPT & & 4 & 13 \\
\hline Al-P & K. A. & 28.5 & 64.2 \\
\hline $\mathrm{Na}$ & $\mathrm{mEq} / 1$ & 146 & 141 \\
\hline $\mathrm{K}$ & & 4.7 & 3.8 \\
\hline $\mathrm{C} 1$ & & 117 & 111 \\
\hline $\mathrm{Ca}$ & $\mathrm{mg} / \mathrm{dl}$ & 7.8 & 8.9 \\
\hline $\mathrm{P}$ & & 2.3 & 2.1 \\
\hline $\mathrm{Mg}$ & & & 2.1 \\
\hline $\mathrm{Fe}$ & $\mu g / d 1$ & 81 & 96 \\
\hline \multicolumn{4}{|l|}{ Blood gas } \\
\hline $\mathrm{PaO}_{2}$ & $\mathrm{mmHg}$ & 93.3 & 104.1 \\
\hline $\mathrm{PaCO}_{2}$ & & 38.5 & 40.9 \\
\hline $\mathrm{pH}-$ & & 7.275 & 7.357 \\
\hline $\mathrm{HCO}_{3}^{-}$ & $\mathrm{mEq} / 1$ & 17.6 & 22.6 \\
\hline \multicolumn{4}{|l|}{ Urine } \\
\hline Volume & $\mathrm{L}$ & $2.0-3.45$ & $1.34-2.04$ \\
\hline $\mathrm{pH}$ & & 6.34 & 6.74 \\
\hline Protein & g/day & 0.60 & 1.6 \\
\hline Glucose & & 3.5 & 8.5 \\
\hline $\mathrm{Ca}$ & $\mathrm{mg} / \mathrm{day}$ & 28.2 & 207.4 \\
\hline $\mathrm{P}$ & & 274.5 & 620.9 \\
\hline Amino-acid nitrogen & $\mathrm{mg} / \mathrm{g} \cdot$ Creat & 703.7 & 1050.0 \\
\hline$\beta_{2}$-microglobulin & $\mathrm{mg} / \mathrm{dl}$ & 5.6 & 1.6 \\
\hline \multicolumn{4}{|l|}{ Renal function } \\
\hline Creatinine clearance & $\mathrm{ml} / \mathrm{min}$ & 16.9 & 81.7 \\
\hline Phosphate clearance & & 12.9 & 29.5 \\
\hline \%Tubular reabsorption & $P$ & 23.6 & 63.9 \\
\hline
\end{tabular}


ど生活全般にわたる運動が著しく困難となつた。 しかし，経済的理由により医療機関を訪れること なく 2 年半放置後, 1980 年 8 月に萩野病院を受診

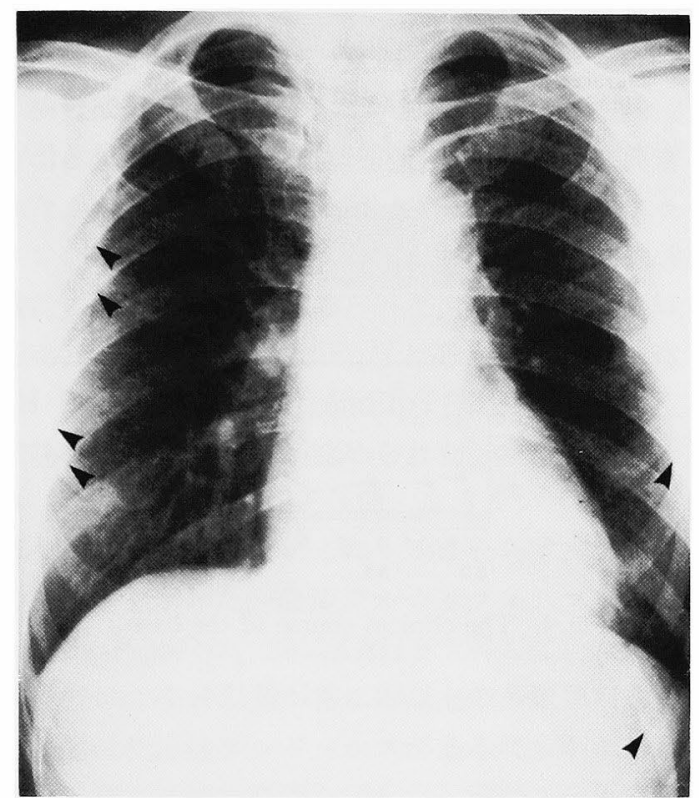

Fig 1a. X-ray of chest showing multiple pseudofractures in ribs (arrows).
した、なおこの時点までビタミン $\mathrm{D}$ 投与の既往は まつたくなかつた。

入院時現症：腰部の前弯が大で, 胸部脊柱の 平坦化した姿勢を示し，歩行はあひる様歩行waddling gaitであつた，右股関節の運動痛・圧痛が顕 著で，そのため右臥位をとれず，また両側胸部第 $8 \sim 9$ 肋骨部の圧痛 呼吸時痛があり,このため に寝返りが困難であつた。両手指のしびれ感，口
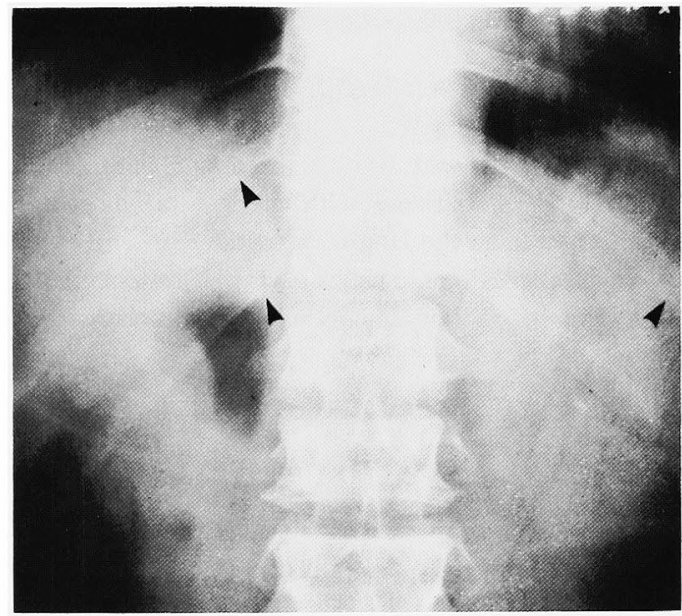

Fig 1b. Pseudofractures in ribs.

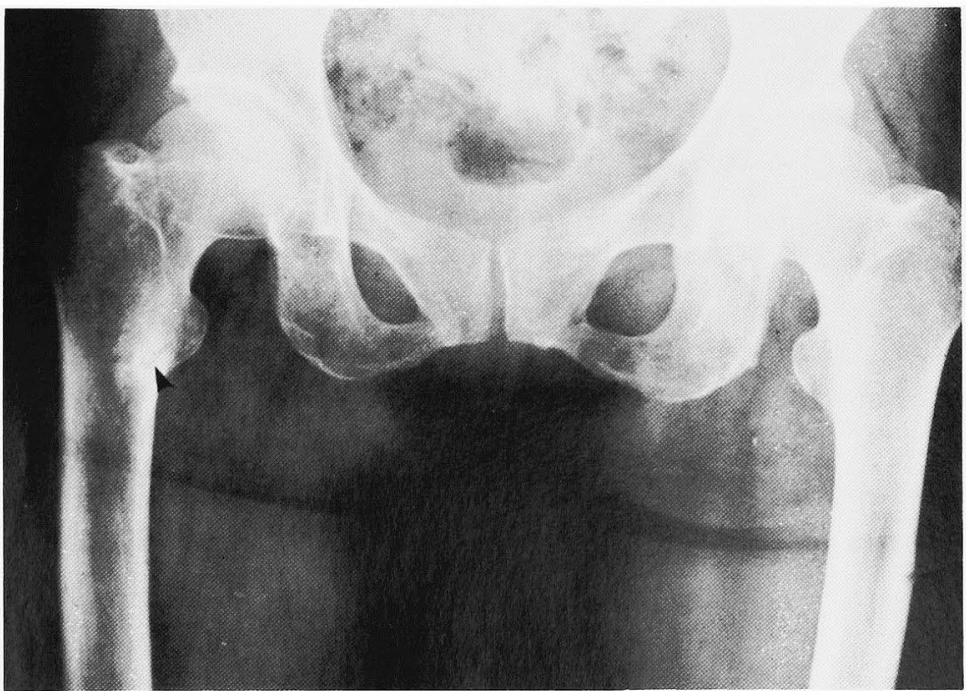

Fig 2. Roentgenogram of the pelvis of the case 1 in September 1980, showing radiolucent Looser's zones at the sites of the minor trochanter of right femur and the middle of the left femoral schaft. 


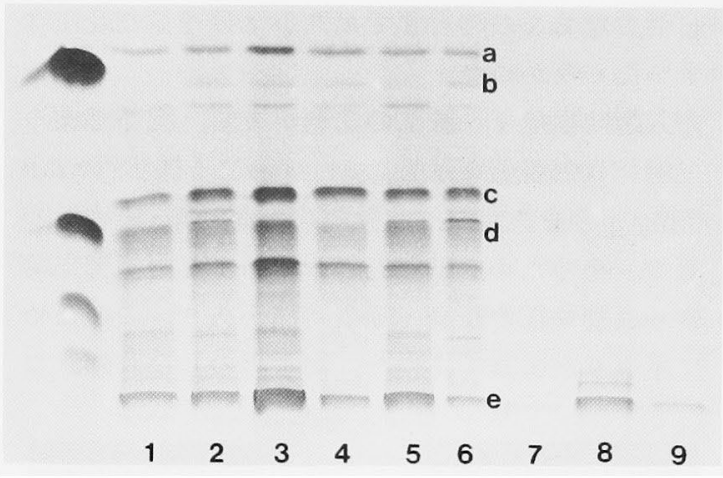

Fig 3. Slab-electrophoretic patterns of urinary proteins.

$1-4$, patients with itai-itai disease 5 , case $2 ; 6$, case $1 ; 7-9$, patients with no itai-itai disease, administered to the Hagino hospital.

a, $\beta_{2}$-microglobulin; $b$, lysozyme ; $c$, retinol binding protein; $d$, immunoglobulin $G$ light-chain; e, albumin.

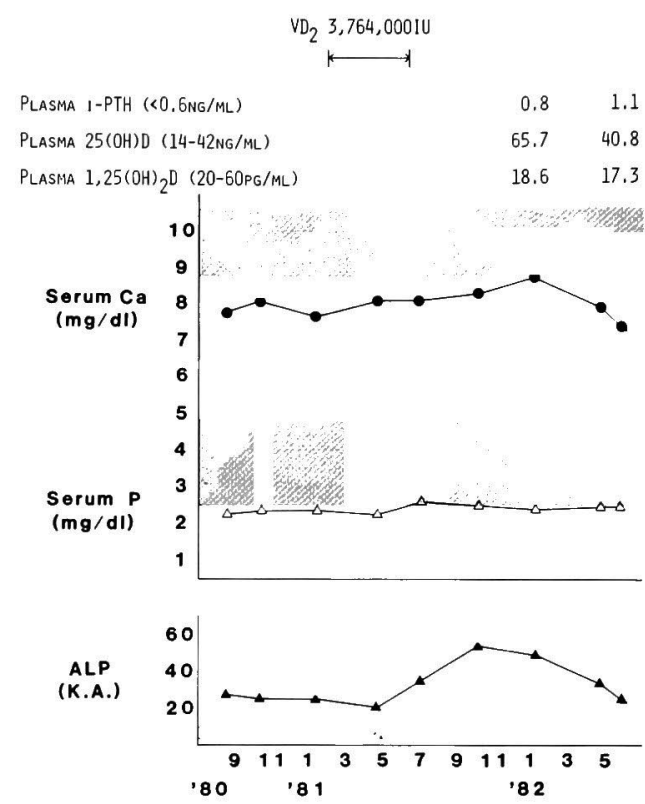

Fig 4. The clinical course of the case 1 .

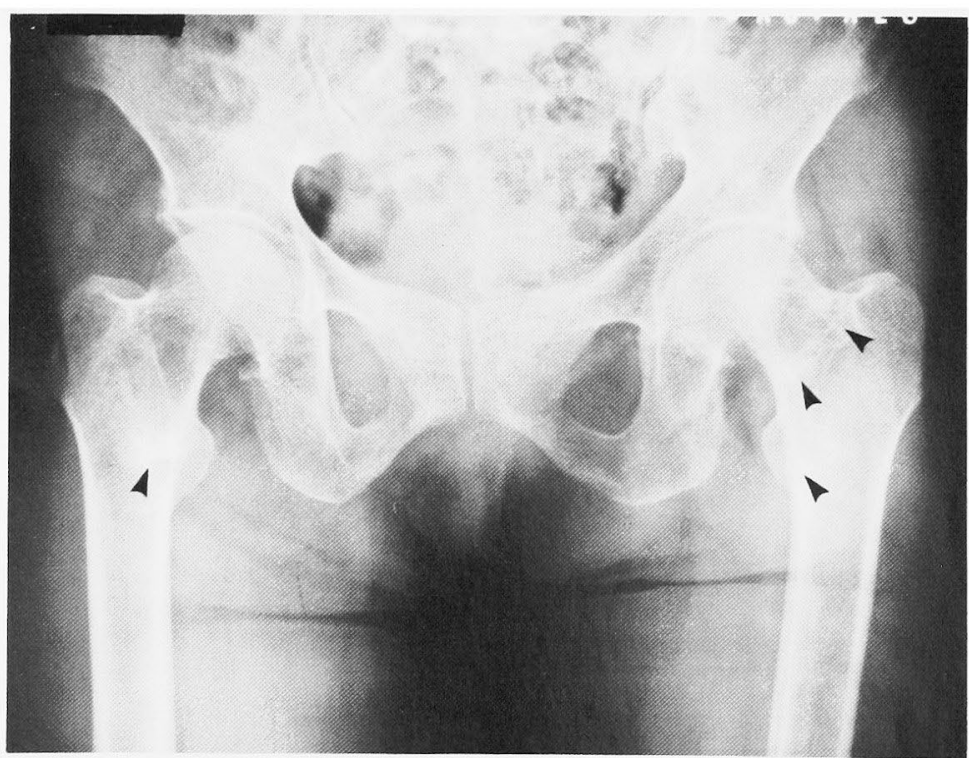

Fig 5. Roentgenogram of the pelvis of the case 2 in July 1981, showing the transverse defect with sclerotic margins (Looser zone) at the site of the femoral neck and sclerotic area at the site of the minor trochanter of both femurs. 
渴・多飲・便秘子及られた。

骨X線像所見（Fig 1a, 1b, Fig 2)：全身骨 にび漫性の骨萎樎があり，左右胁骨に 9 力所，右 大腿骨小転子部，左大眼骨骨幹部外側にそれぞれ 1 力所の合計11力所に骨改変層を認めた。また胸 郭に軽度のつりが放状の変形を認めた。

検査成績 (Table 2)：赤血球数 328 万, Hb 9.2 $\mathrm{g} / \mathrm{dl}$ と貧血を認めた。血清総蛋白, 蛋白分画に異常 はなかつた. BUN $27 \mathrm{mg} / \mathrm{dl}$ とやや高く,クレアチ ニン $2.7 \mathrm{mg} / \mathrm{dl}$ と高值, GFR $16.9 \mathrm{ml} / \mathrm{min}$ と乐球体 機能の著しい低下が認められた。血清カリウムは 正常.クロールは $117 \mathrm{mEq} / l$ と高く，血液ガスは $\mathrm{pH} 7.275, \mathrm{HCO}_{3}^{-}-17.6 \mathrm{mEq} / l$ と高クロール血性 代謝性アシドーシスが認められた，血清カルシウ ム（Ca）は7.8mg/dl と低值，血清リン (P) も糸 球体機能が低下しているにもかかわらず,2.3mg/ dlと低值を示した。血清アルカリフォスファター ぜ(Alk·P-ase)は，28.5KAUと上昇していた。尿 所見では，1 日禾量が常に $2 l$ 以上の多瓜傾向を示 し， pHは代謝性アシドーシスがあるにるかかから ず，6.34と比較的高值を示した，尿糖・尿蛋白陽 性であり，尿蛋白電気泳動像では尿細管型を示し た(Fig 3)。尿アミノ窒素， $\beta_{2}$ マイクログロブリ ンも増加していた。

経過（Fig 4）：1980年8月入院後も血清 $\mathrm{Ca}$,
Pの低值とAlk-P-aseの高值が続いた.1981年 1 月 末から6月中旬までビタミン $\mathrm{D}_{2}$ を経口と矨注投 与で, 総量 376 万 4 千単位使用した。. $\mathrm{D}_{2}$ 投与 $4 \sim 6$ カ月後の同年10月から12月にかけてAlk-P-ase と Caの上昇がみられたが，その後再び減少した。自 覚的には肋骨痛は軽減したが，右股関節痛はなお 持続した，X線所見では左大腿骨骨改变層の蓿 小・石死化が認められた。

症例 2.63才 女性。

初診：1981年5月.

主訴：左股関節痛とそのための歩行障害。

家族歴： 姑（夫の母）が70才頃より下肢痛を 訴え，そのために跛行をきたし75才で死亡。

既往歴・生活歴（Table 3)：生来著患なく健 康であつた。1936年（18才）よりCd污染地域であ る現住所地の婦負郡八尾町西神通に居住する。家 莱は農業である。飲料・生活用の水は，約10年前 に上水道が設置されるまでは，神通川よりの用水 の水を直接用いたり，また井戸」(田に㱐が入ら ない冬季水が出ない，いわゆる「冬枯れする井 戸」)の水を用いた，したがつて冬季は用水の水を 使用していた。

現病歴 (Table 3)：49才（1967年）のとき， 住民健康診査において尿糖 - 氺蛋白陽性を指摘さ れ，要観察者の半定をらける。しかし1969年6月

Table 3. Present, personal and social history of the case 2.

\begin{tabular}{|c|c|c|c|c|c|c|c|c|}
\hline & 西 琹 & 年命 & 現 & 病 & 歴 & 生 & 活 & 栤 \\
\hline 大正? & 1918 & & \multicolumn{6}{|c|}{ 八尾町杉田小泉（井田川水采）で生まれる。 } \\
\hline 昭和 11 & 1936 & $18 才$ & \multicolumn{6}{|c|}{ 結婚のため八尾町西神通へ移る。 } \\
\hline 13 & 1938 & 207 & \multicolumn{6}{|l|}{ 第一子出阵。 } \\
\hline & & & \multicolumn{6}{|l|}{ 夫戦死。 } \\
\hline 35 & 1960 & $42 才$ & \multicolumn{6}{|c|}{ 義母「1」病にて死亡(75才）。 } \\
\hline 42 & 1967 & $49 才$ & \multicolumn{6}{|c|}{ 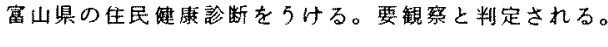 } \\
\hline 44 & 1969 & 517 & \multicolumn{6}{|c|}{ 要䚇察を解除される。 } \\
\hline 55 & 1980 & $62 才$ & \multicolumn{6}{|c|}{ 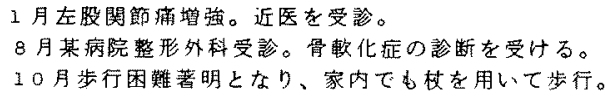 } \\
\hline 56 & 1981 & 637 & \multicolumn{6}{|c|}{ 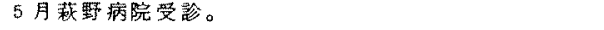 } \\
\hline
\end{tabular}


に症例 1 と同様に要観察の判定を解除されてい た。1980年 1 月歩行時に左股関節痛が出現し，そ のために歩行が著しく困難となつた。同年 8 月某 病院整形外科で骨軟化症と診断され, 活性型ビタ ミン $\mathrm{D}_{3}$ の投薬を受け 4 週間服用した。 10 月には同 部位の運動痛が著明となり，家内でも杖歩行とな つた，症状の改善をみないため，1981年 5 月萩野 病院を受診した。な扎1980年 8 月以前にはビタミ ンDによる治療歴はなかつた。

入院時現症：左凸の胸椎側弯を示し，また左 股関節の運動痛と王痛が顕著で，そのために左跛 行を示した。

骨X線像所見： 全身骨のび漫性萎縮を認め た. 脊柱は第 4 胸椎より左凸, 腰椎は右凸のS字状 側弯を呈した。第 $3 ， 4$ 腰椎に骨棘を認めた。両 大腿骨皮質の菲薄化と両転子部の骨硬化像ならび に左大服骨頝部に骨改変層を認めた（Fig 5).

検查成績 (Table 2): 赤血球数 341 万, $\mathrm{Hb}$ $12.1 \mathrm{~g} / \mathrm{dl}$ と明らかな盆血はなく，またFBS $90 \mathrm{mg} /$ $\mathrm{dl}$ と正常であつた. BUN, クレアチニン值も異常 なく, GFR $81.7 \mathrm{ml} / \mathrm{min}$ 系球体機能は正常であ つた，電解質ではクロールが $111 \mathrm{mEq} / l$ と高く，血 液ガス $\mathrm{pH} 7.357, \mathrm{HCO}_{3}-22.6 \mathrm{mEq} / l$ と高クロ一 ル血性代謝性フシドーシスが認められた。カリウ ムは $3.8 \mathrm{mEq} / l$ と正常範用内であつた。血清 $\mathrm{Ca}$ $8.9 \mathrm{mg} / \mathrm{dl}, \mathrm{P} 2.1 \mathrm{mg} / \mathrm{dl}$ といずれも低值を示し, Alk.P-aseは64.2KAUと著明に上算していた。

尿所見では, $\mathrm{pH} 6.74$ とアシドーシスがあるに すかかわらず，比較的高值を示した，尿糖 尿蛋 白陽性であり，尿蛋白電気泳動では多数の低分子

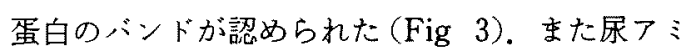
，窒素， $\beta_{2}$-マイクログロブリンも増加していた。 尿中Ca排出量は $207.4 \mathrm{mg} /$ 日と多く, またりンク リアランスの增加, \% TRPの低下があり, 尿中へ のリン排泄の増加が示された。

経過（Fig 6)：血清Caは低值から正常下限 值を示し, 血清Pは常に $2.5 \mathrm{mg} / \mathrm{dl}$ 以下の低值であ つた. Alk-P-aseは39.0〜13.0KAUと常に高值を 示した。

$25(\mathrm{OH}) \mathrm{D}, 1 \alpha, 25(\mathrm{OH})_{2} \mathbf{D}$ 值 (Table 4, Fig

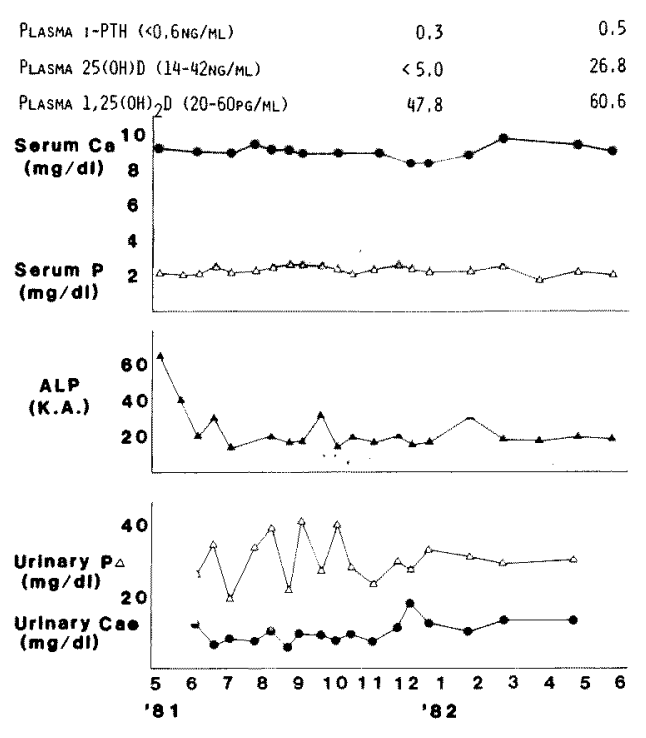

Fig 6. The clinical course of the case 2 .

$4,6)$ ；2症例の血浆25-hydroxy-vitamin D (25$(\mathrm{OH}) \mathrm{D})$ competitive protein binding assay法 で, $1 \alpha, 25$-dihydroxyvitamin $\mathrm{D}\left(1 \alpha, 25(\mathrm{OH})_{2}\right.$

D) をradioreceptor assay法によつて, 1981年12 月と1982年 6 月の 2 回測定した。な尿中 $25(\mathrm{OH}) \mathrm{D}$ competitive protein binding assay法 で，1982年12月に測定した。さらに副甲状腺ホル モン(PTH)をC末端に特異的なradioimmuno assay法により測定した。症例 1 のPTH値は, 0.8 , $1.1 \mathrm{ng} / \mathrm{ml}$ と軽度上昇していた血浆 $25(\mathrm{OH}) \mathrm{D} 12$ 月の測定で $65.7 \mathrm{ng} / \mathrm{ml}$ とや高めであつたが翌年 の 6 月は $40.8 \mathrm{ng} / \mathrm{ml}$ と正常範曲を示した。 $1 \alpha, 25$ $(\mathrm{OH})_{2} \mathrm{D}$ 值は $18.6,17.3 \mathrm{pg} / \mathrm{ml}$ と 2 回の測定值と も正常値以下であつた。

症例 2 のTHは, 血清Caが低い傾向にあるに もかかわらず, 0.3,0.5ng/ml と低值を示した。血 浆25(OH)Dは12月には測定感度以下であつたが, 6 月の測定では $26.8 \mathrm{ng} / \mathrm{ml}$ と正常範囲であつた。 $1 \alpha, 25(\mathrm{OH})_{2} \mathrm{D}$ 值は47.6, $60.8 \mathrm{pg} / \mathrm{ml}$ と 2 回の測 定値は正常値を示した。

血中・尿中ならびに自家米中Cd值（Table 5, Fig 7)：全血ならびに尿を硫・硝酸で湿式灰化 後, ammonium pyrrolidine dithiocarbamate- 
Table 4. Laboratory data of $\mathrm{Ca}$ and $\mathrm{P}$ metabolism on two cases.

\begin{tabular}{|c|c|c|c|c|c|c|c|}
\hline & & \multicolumn{2}{|c|}{ Case 1} & \multicolumn{2}{|c|}{ Case 2} & \multirow{2}{*}{ Normal } & \multirow{2}{*}{ range } \\
\hline & & Dec. 19,1981 & June 12,1982 & Dec. 19,1981 & June 12,1982 & & \\
\hline Serum calcium & $\mathrm{mg} / \mathrm{dl}$ & 8.7 & 8.0 & 8.3 & 9.1 & 8.8 & 10.5 \\
\hline Serum phosphate & $\mathrm{mg} / \mathrm{d} 1$ & 2.4 & 2.6 & 2.2 & 1.8 & 2.5 & 4.8 \\
\hline Alkaline phosphatase & K.A.U. & 50.0 & 22.9 & 16.2 & 17.2 & 3 & 10 \\
\hline Plasma i-PTH & $\mathrm{ng} / \mathrm{ml}$ & 0.8 & 1.1 & 0.3 & 0.5 & $<$ & 0.6 \\
\hline Urinary calcium & mg/day & 28.2 & 40.0 & 250.9 & 347.2 & 50 & 200 \\
\hline P clearance & $\mathrm{ml} / \mathrm{min}$ & 12.9 & 12.7 & 29.5 & 40.1 & 5 & 12 \\
\hline TRP & $\%$ & 23.6 & 37.1 & 63.9 & 54.8 & 82 & 95 \\
\hline Creatinine clearance & $\mathrm{ml} / \mathrm{min}$ & 16.9 & 20.2 & 81.7 & 88.8 & 70 & 130 \\
\hline Plasma 25(OH)D & $\mathrm{ng} / \mathrm{ml}$ & 65.7 & 40.0 & $<5.0$ & 26.8 & 14 & 42 \\
\hline Plasma $1,25(\mathrm{OH})_{2} \mathrm{D}$ & $\mathrm{pg} / \mathrm{ml}$ & 18.6 & 17.3 & 47.8 & 60.0 & 20 & 60 \\
\hline Urinary $25(\mathrm{OH}) \mathrm{D}^{*}$ & $\mathrm{ng} / \mathrm{dl}$ & & 8.3 & & 8.0 & 0.4 & 43 \\
\hline
\end{tabular}

* Urinary 25(OH)D were measured in December, 1982.

Table 5. Cadmium concentrations in blood, urine and homegrown rice in the two cases.

\begin{tabular}{cccc}
\hline & $\begin{array}{c}\text { Blood } \\
\text { ng/m1 }\end{array}$ & $\begin{array}{c}\text { Urine } \\
\mu \mathrm{g} / \mathrm{I}\end{array}$ & $\begin{array}{c}\text { Rice } \\
\mathrm{ppm}\end{array}$ \\
\hline Case 1 & 26.8 & 5.7 & 0.22 \\
Case 2 & $8.9 \pm 2.4$ & $15.5 \pm 5.3$ & 0.55 \\
\hline
\end{tabular}

methyl isobutyl ketone (APDC-MIBK) で抽出 し，無炎原子吸光法でCdを測定した。また 2 症例 宅の自家精白米を低温灰化装置で灰化し，灰分を 濃塩酸で加熱分解後 $1 \%$ 温硝酸で溶解し，無炎原 子吸光法でCdを測定した。

症例 1 の, 1982年 2 月の血中, 尿中Cd值はそれ ぞれ26.8ng/ml, $5.7 \mu \mathrm{g} /$ /であつた。症例 2 の尿中 Cd值の推移は, Fig 7に示すよらに変動がみられ たが，尿中 1 日排出量は $25 \mu \mathrm{g}$ 前後であつた。血中 $\mathrm{Cd}$ 值快, 11月の测定值が $16,14 \mathrm{ng} / \mathrm{ml}$ でつたが, 他の時期の值は活ぼ一定で $8.0 \mathrm{ng} / \mathrm{ml}$ 前後であつ た。

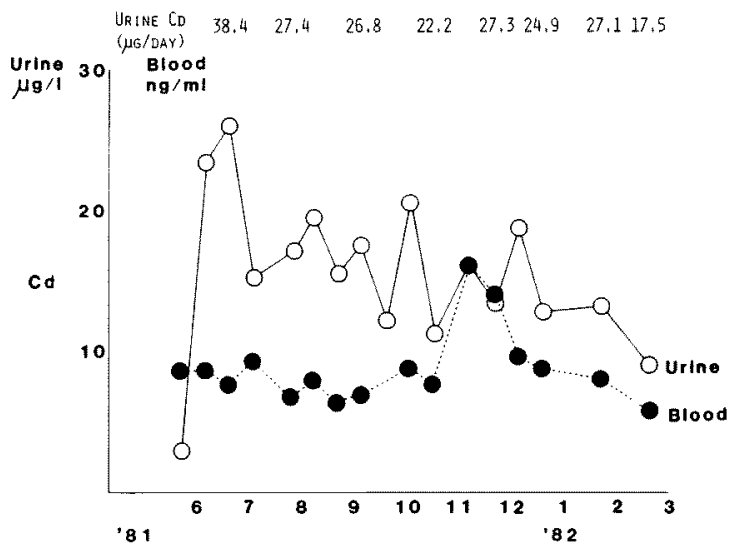

Fig 7. Changes in cadmium concentrations in blood and urine of the case 2 .

\section{考案}

イ病は富山県神通川流域のCd污染地域に発生 した，主として閉経期後の女性に多くみられる運 動痛・運動困難を主訴とする骨疾患であり，本症 のもつとも特徽的な所見は骨軟化症である ${ }^{155)}$ ，亦 た骨病変とともに，当初から糖尿・蛋白尿が指摘

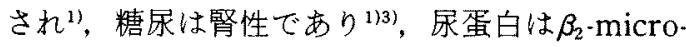


globulin, retinol-binding protein, lysozymeなど の低分子蛋白尿であることが知られだ，また全 般性アミノ酸尿や尿細管リン再吸收率, PSP 15分 值ならびにPAHクリアランスの低下.ささらに高ク ロール血性アシドーシスなど近位尿細管の多発性 の機能障害があることも明らかたされた7)

本 2 例では，低Ca血症・低P血症と血清Alk-Paseの高値があり，骨X線像所見では明らかな骨改 变層が認められ，典型的な骨軟化症の像を示して いる。他方，糖尿・低分子蛋白尿 $7 ミ /$ 酸尿 高クロール血性アシドーシスならびにリン再吸収 率の低下などを認め，尿細管の多発性の機能障害 も認められる。

ここにみられる骨軟化症と尿細管障害の関連 は，後者は現病歴より1967年に（当時症例 1 は53 才, 症例 2 は49才）富山県が初めて央施した神通 川流域住民健康對査に执いて，すでに尿蛋白 尿 糖陽性所見として指摘されている。この陽性所見 に示される腎障害発症の正確な時期は，1967年以 前には検查を受ける機会がなく不明である。

他方骨軟化症は，症例 1 は1967年に右股関節痛 と跛行がみられ，また健診で右股関節開排制限を 指摘されていることなどから，腎障害とともにす でに存在していたと考学られる。その後徐々に骨 症状は悪化し, 約10年後の1978年には歩行をはじ め運動障害が顕著となつている。症例 2 む，1967 年に腎障害を指摘されてから，13年後に著しい左 股関節痛をきたし，骨軟化症と診断されている。

この 2 症例の経過は，腎障害はすでに15年前以 上の1967年以前に発症し，その後徐々に骨症状が 出現し，典型的な骨軟化症を呈したことを示して いる。すなわち 2 例の骨軟化症は％％TRPの低下 ならびに高クロール血アシドーシスの存在に示さ れる高度の尿細管機能障害によると考光られる。

イ病の骨軟化症の原因は，ビタミンD年をを含

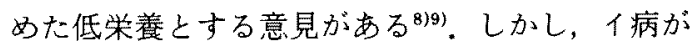
富山平野の神通川流域にのみ限局して発生した疫 学的事実)，またこの地域は豊かな㪍倉地帯であ り，さらに神通川や富山湾の漁場を控え，山間部 と異なり魚貝類も豊富であることなとをを考慮する
と，この地域のみ低栄盖であつたとは考えられな い。まして戦後 20 数年後に発症した本 2 例に打い ては，低栄㽰が原因とは考学られず，現に偏食は みられていない，さらに2 症例とも60才までは農 作業に従事して倣り，日光不足によるビタミンD 欠乏考光ら机ないすすなわち本 2 例の骨軟化症 の原因は，栄養性あるいは日照不走によるビタ ンD欠之は考えられず，娭査所見ならびに経過か らは，尿細管機能異常がCaやPなどのミネラル代 謝異常をるたらし，さらに骨軟化症をひき扢こし たと考点られる。

次に尿細管障害の原因に関して，2例に扮计る Cdの影響について検討する。生活歷に示したよう に, 2 例はCd污染地域に 40 年以上居住し, Cd土壤 污染対策指定をうけた水田 (Cd 1ppm以上を含む 玄米を産出する水田として作付を停止されている 水田）を症例 1 は $1.5 \mathrm{ha}$, 症例 2 は $1.2 \mathrm{ha}$ 所有して いる，また指定外の水田等では，現在も米や野菜 を自家生産しているが, Table 5に示したように昭 和56年度産精白米中のCd濃度は, 症例 1 か 0.22 $\mathrm{ppm}$ ，症例 2 が $0.55 \mathrm{ppm}$ と，報告されている非污 染米0.15 $\mathrm{ppm}^{100}$ に比較し高い值である。ちなみに， 神通川流域Cd污染地区の土壤改良後の 1 患者宅 の精白米中Cd値は0.06ppmであつた（青島，未発 表).これらのことから，2症例てはCd污染土壤よ りの作物の掑取と，以前は神通川からの用水の水 を直接飲用していた事実から，これらのものを通 してCdが体内に多量にとり込まれ，蓄積されたと 考党られる。この体内に異常蓄積したCdが尿細管 障害の原因と考えられる，現在も2 例の血中，尿 中Cd値は，日本人の平均值 ${ }^{11}$ 上り高く，以前にCd の暴露があつたこと,さらに現在も米などからCd の暴露が続いていることを示している。

Cd以外にも多くの尿細管障害の原因が知られ ている12)．2例に怙いては血清蛋白分画に異常な く, 遺伝疾患の病歴・所見もない。さらに医薬品 の服用歴むなく、とくにビタミンDの治療歴・服 用歷はまつたくなかつた。イ病の腎障害の原因は ビタミンD過剩投与によるといら見解もあつた $か^{8899}$ ，ビタミン D治療以前に尿細管障害が存在 
し3), 病理的にもビタミン D中毒症の腎所見とは 異なり5), さらにイ病発生地域住民に, 亿病と同様 の尿所見がみられ腎障害の発生があること深など から考学難い

以上ををとると，2例はCd濃厚污染地に居住 し，自家産米ならびに尿中・血中Cd值が高く $\mathrm{Cd}$ の異常暴露が認められ，さらに1967年以前に発症 したと考えられる泉細管の多発性の機能障害があ り，また骨改変層 (骨軟化症) が認められること より、イ病と診断した。これはイ病の認定条件 ${ }^{131} に$ 合致し，またこれまで報告されているイ病13)7と も一致している。1980－81年初診の本 2 症例は, 現在も新たな発症が污染地区住民の中にあること を示している。

次に 2 症例の $\mathrm{P}$ 代謝とビタミン $\mathrm{D}$ 代謝に限つて 検討する。一般に病細管障害が骨軟化症の成因と なることはよく知られている しては，尿細管の再吸収障害による尿中へのPの リークによる低リン酸血症や，重炭酸イオンの尿 中变失による尿細管性アシドーシスの存在などが 考兄られる3114)、イ病において低りン酸血症は，血 清Alk-P-aseの高値とともに, 報告の当初から注 目されている特徵的な所見である ${ }^{1 / 4)}$ 本 2 例は $2.5 \mathrm{mg} / \mathrm{dl}$ 以下の低りン酸血症が持続して認めら れた（Fig 4，6). 症例 2 は, Ccr $80 \mathrm{ml} / \mathrm{min}$ 正 常であるが％ＴRRは50～60\%と低下し，症例 1 ではCcr $20 \mathrm{ml} / \mathrm{min}$ ％ TRP $40 \%$ 以下と著明な 低下を示した。2 例の低りン酸血症は，この尿細 管におけるPの再吸収障害によると考克られる。 症例 2 ではPTHの増加はなく、明らかな二次性副 甲状腺機能六進症は認められなかつた。すなわち PTHによるP利尿の亢進はないものと考えられ た。 2 症例に打いて高クロール血性代謝性フシ ドーシスも認められ，この病態もまた骨石灰化障 害に関与していると考えられる。

近年ビタミン D代謝研究の発展により, 骨軟化 症とビタミンD代謝異常との関連が注目されてい

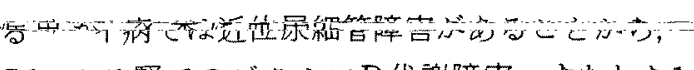
$\mathrm{Cd}$ による腎でのビタミンD代謝障害，すなわち1 $\alpha$-hydroxylase活性低下による $1 \alpha, 25(\mathrm{OH})_{2} \mathrm{D}$ 産
生障害があり，そのために骨軟化症となるのでは ないかと推測されてきだ5 しかしイ病に拈いて ビタミンD代謝物を測定した報告はこれまでなか つた. Table 3に示したよ5に, $1 \alpha, 25(\mathrm{OH})_{2} \mathrm{D}$ 值は, 症例 1 では 2 回の測定值とも正常値以下で あつたことより，尿細管における25(OH)Dの1 $\alpha$ 水酸化反応の低下が考点られた。それ対し，症 例 2 の $1 \alpha, 25(\mathrm{OH})_{2} \mathrm{D}$ 値は, 2 回の測定値之も正 常であつた。症例 1，2 はともに高度の尿細管障害 がみられるが, 症例 1 ではさらに糸球体機能の低 下も認められた。病に招いても尿細管障害が進 展するとglomerulo-tubular balanceを保つ形で 夈球体機能低下を括こすことが指摘されてい $3^{16)}$.この 2 例の結果は, 䒺球体機能低下の顕著で はない尿細管障害例(症例 2 )では, $1 \alpha, 25(\mathrm{OH})_{2}$ Dの産生低下はみられず，尿細管障害が系球体機 能低下をむたらすはどに進展した例（症例 1 ）で は， $1 \alpha, 25(\mathrm{OH})_{2} \mathrm{D}$ 産生障害があることを示して いる， 2 症例はともに明らかな骨改変㬝（骨軟化 症）があることから， $1 \alpha ， 25(\mathrm{OH})_{2} \mathrm{D}$ は 2 例の骨 軟化症の成因には直接関与していないと考克られ る.この点に関しては, 最近血中 $1 \alpha, 25(\mathrm{OH})_{2} \mathrm{D}$ が正常である骨軟化症例が報告されている ${ }^{17118)}$.

$25(\mathrm{OH}) \mathrm{D}$ は，症例 1 は1981年12月にやや高值 を示したが，これは同年1月から6月までのビタ ミン $\mathrm{D}_{2}$ による治療の影響と考えられる，症例 2 は，12月は測定感度以下の低値，6月は正常値を 示していた. $25(\mathrm{OH})$ Dは冬季に低く, 夏季に高い 季節変動を示すことが知られているが，本例もこ の季節変動を示したと考えられる。しかし冬季の $25(\mathrm{OH}) \mathrm{D}$ 值は, 正常者の值より著しく低い. 著者 らは，イ病患者の尿中にビタミンD結合蛋白が漏

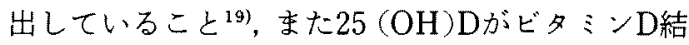
合蛋白とともに尿中八漏出していることを明らか にした ${ }^{20)}$. 尿中 $25(\mathrm{OH}) \mathrm{D}$ 值は, 症例 1 が8.3ng/ $\mathrm{dl}$, 症例 2 は $8.0 \mathrm{ng} / \mathrm{dl}$ と, 健常者の平均值 $0.43 \mathrm{ng} /$ dlk比し20倍む高濃度であつた（Table 4)。この

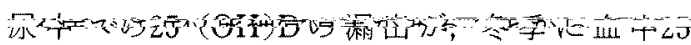
$(\mathrm{OH}) \mathrm{D}$ 值が著減した一つの理由と考兄られる.イ 病におけるビタミンD代謝異常については，留に 
抬ける1 $\alpha$-hydroxylase活性障害のみならず，25 $(\mathrm{OH}) \mathrm{D}$ の代謝障害を含め今後の検討が必要であ る.

\section{結語}

1967年の住民健康調査で糖尿 蛋白尿を指摘さ れ，1980～81年にX線像上明白な骨改变層（骨軟 化症）を認め， イ病と診断した 2 症例について， 本病の発症機転ならびにビタミン D代謝に関して 検討を加えて報告した。

謝辞御助言いただいた国立公害研究所環境保健部 斎 藤寛空長，東北大学第二内科 古川洋太郎講師，尿中 25 (OH)Dの測定ならびにスラブ電気泳動法による瓜蛋白の 分析をしていたたいた富山医科薬科大学薬学部衛生生物化 学 小橋恭一教授，近藤真理子さんに深謝致します。

\section{文献}

1）中川昭忠：富山県に発生した骨軟化症の研究（所 謂いたいいたい病)。金沢医理学丵書 $56: 1$, 1960.

2)福島匡昭, 他：イタイイタイ病発生地住民の腎障 害に関与る缤学的研究. (第 1 報)神通川流域住民 の尿険查成績。日圌誌 $21 ： 65 ， 1974$.

3）斎藤寛，他：カドミウム腎障害一慢性カト゚ミウ ム中毒打よびいわゆるイイイタイ病の腎病変と 骨病変一, 日本臨床 $36: 3431 ， 1978$.

4) 石崎有信, 福島匡昭：イタイイタイ病、日衛誌 $23: 271,1968$.

5）暒川欽一郎，他：富山県下に地方病的に多発した 骨疾患一い㕲る「イタイイタイ病」について。 日病会誌 $46 ： 655 ， 1957$.

6）金井正光，他：イタイイタイ病患者とその家族に おける烁中怙よび血中 $\beta_{2}$-microglobulin測定の臨 床的意義について。最新医学 $31: 1793,1976$.

7) 武内重五郎, 他：イタイイタイ病の腎障害. 内科 $21: 876,1968$.
8) 武内重五郎, 内藤周幸：イタイイタイ病発病要因 をめぐって。医学のあゆみ 80:609，1972。

9）武内重五郎：イタイイタイ病の病因一カドミウム 原因論に対する批判一 日本臨床 $31: 2048$, 1973.

10）福島匡昭，他：神通川流域の農家保有米カドミウ 么濃度について。语誌 $28 ： 406 ， 1973$.

11）野牛弘，二島太一郎：血液・尿化学椧査一その 数值をどら読もかーカトミウム。日本臨床 40 ： $428,1982$.

12) Chesney RW: Etiology and Pathogenesis of the Fanconi Syndrome. Mineral Electrolyte Metab $4: 303,1980$

13）本多重雄：イタイイタイ病の発見から補償まで。 公衆衛生 $39: 614,1975$.

14) Habener JF and Mahaffey JE: Osteomalacia and disorders of vitamin D metabolism. Ann Rev Med 29:327, 1978.

15）碽田立雄：ビタミンDの代謝異常と骨軟化庭。骨 代謝 9:367，1976。

16）篗田眖, 由利健久：イタイイタイ病患者の内科 的所見とくに腎病变の推䔟、環境保健レポート $45: 114,1979$

17) Eastwood JB, et al: Normal plasma-1,25 $(\mathrm{OH})_{2}$-vitamin-D concentrations in nutritional osteomalacia. Lancet 1: 1377, 1979

18) Rasmussen $\mathrm{H}$, et al: $1,25(\mathrm{OH})_{2} \mathrm{D}_{3}$ is not the only $\mathrm{D}$ metabolite involved in the pathogenesis of osteomalacia. Amer J Med 69:360, 1980

19) Teranishi $\mathrm{H}$, et al: Demonstration of vitamin D-binding protein (Gc-globulin) in the urine of Itai-itai disease patients. Toxicol Lett 15:7, 1983.

20）加須屋実，他：イタイイタイ病の尿中ビタミン D 結合蛋白（Gc-globulin）と展中ならびに血中25OH-Dの動向。環境保健レポート 49:160, 1983. 